\title{
Adhesion of Oral Streptococci from a Flowing Suspension to Uncoated and Albumin-coated Surfaces
}

\author{
By INA H. PRATT-TERPSTRA, * ANTON H. WEERKAMP AND \\ HENK J. BUSSCHER \\ Dental School, University of Groningen, Antonius Deusinglaan 1, 9713 AV Groningen, \\ The Netherlands
}

(Received 10 March 1987; revised 19 May 1987)

\begin{abstract}
A flow cell system was developed which allowed the study of bacterial adhesion to solid substrata at well-defined shear rates. In addition, the system enabled the solid surfaces to be coated with a proteinaceous film under exactly the same shear conditions. In this flow cell system, adhesion of three strains of oral streptococci from a phosphate-buffered solution onto three different substrata was studied as a function of time in the absence and presence of a bovine serum albumin (BSA) coating at a shear rate of $21 \mathrm{~s}^{-1}$. To obtain a wide range in surface free energies $(\gamma)$ representative strains $\left(\gamma_{\mathrm{b}} 38-117 \mathrm{~mJ} \mathrm{~m}^{-2}\right)$ and solid substrata $\left(\gamma_{\mathrm{s}} 20-109 \mathrm{~mJ}\right.$ $\mathrm{m}^{-2}$ ) were selected. The number of bacteria adhering was counted microscopically. In the absence of a BSA coating a linear relation was found between the number of bacteria adhering at saturation $\left(n_{\mathrm{b} . \mathrm{s}}\right)$ and the calculated interfacial free energy of adhesion $\left(\Delta F_{\mathrm{adh}}\right)$ for each of the three strains. In the presence of a BSA coating the number of bacteria adhering was greatly decreased in all cases. However, despite the presence of the BSA coating there was still a linear relation between the number of bacteria adhering at saturation and the interfacial free energy of adhesion, calculated on the basis of the surface free energy of the uncoated substrata. It can be concluded that the bare, uncoated substratum still influenced bacterial adhesion in spite of the marked influence of a BSA coating.
\end{abstract}

\section{INTRODUCTION}

The adhesion of bacteria to a wide variety of materials has been the subject of many studies. These have involved specific interactions between complementary surface components (Gibbons, 1980), physico-chemical surface characteristics such as charge and hydrophobicity (Rosenberg et al., 1980; Doyle et al., 1982; Weerkamp et al., 1984) and thermodynamic parameters (Absolom et al., 1983; Busscher et al., 1984; Uyen et al., 1985; Fletcher \& Pringle, 1985). In an approach in which electrical charge interactions are neglected adhesion can be predicted as a result of the interfacial free energy balance. According to Absolom et al. (1983) adhesion will be energetically favourable if

$$
\Delta F_{\mathrm{adh}}=\gamma_{\mathrm{sb}}-\gamma_{\mathrm{sl}}-\gamma_{\mathrm{bl}}<0
$$

where

$\Delta F_{\text {adh }}$ is the interfacial free energy of adhesion

$\gamma_{\mathrm{sb}}$ is the solid-bacterium interfacial free energy

$\gamma_{\mathrm{sl}}$ is the solid-liquid interfacial free energy

$\gamma_{\mathrm{bl}}$ is the bacterium-liquid interfacial free energy

Adhesion will be energetically unfavourable if

$$
\Delta F_{\mathrm{adh}}>0
$$

Abbreviation: FEP, fluoroethylenepropylene copolymer. 
The interfacial free energies can be calculated from an approach based upon separating surface free energies into a dispersion $\left(\gamma^{\mathrm{d}}\right)$ and a polar component $\left(\gamma^{\mathrm{P}}\right)$ denoting van der Waals interactions and the capacity to donate or accept hydrogen ions respectively (van Oss et al., 1987). According to the geometric mean equation the interfacial free energy between any two surfaces 1 and 2 can be expressed in its dispersion and polar components by

$$
\gamma_{1,2}=\gamma_{1}+\gamma_{2}-2\left(\gamma_{1}^{\mathrm{d}} \gamma_{2}^{\mathrm{d}}\right)^{\frac{1}{2}}-2\left(\gamma_{1}^{\mathrm{P}} \gamma_{2}^{\mathrm{P}}\right)^{\frac{1}{2}}
$$

Uyen et al. (1985) observed, using oral streptococci, that the highest numbers of bacteria adhering at saturation occurred in systems for which $\Delta F_{\text {adh }}$ is most negative. Subsequently, Busscher $e$ al. (1986) noted that reversible adhesion was associated with a positive $\Delta F_{\text {adh }}$ while irreversible adhesion was associated with negative $\Delta F_{\text {adh }}$ values.

Most bacterial adhesion experiments have been done under more or less static conditions, with poorly controlled hydrodynamics, irreproducible rinsing conditions and frequent passages of liquid-air interfaces before fixation of the attached bacteria has taken place. Thus, the bacteria actually counted represent only those that had resisted all these different forces of unknown magnitude. A quantitative study of adhesion requires control of these parameters, which can be obtained in a continuous flow system (Rutter \& Leech, 1980).

In biological environments, including the oral cavity, all exposed surfaces will rapidly adsorb a proteinaceous coating (Horbett, 1982). Fletcher (1976) reported that adhesion of marine bacteria to solid substrata was markedly reduced by a proteinaceous film. Although the conditioning film clearly affects the surface properties of the solid substratum, little is known about the relative contribution to bacterial adhesion of the solid substratum and the adsorbed protein layer. Schakenraad et al. (1986), in a study on the influence of surface free energy on growth and spreading of human fibroblasts in the absence and presence of serum proteins, concluded that an influence of the bare underlying substratum was still evident after protein coating. For more or less static systems, Fletcher \& Loeb $(1976,1979)$ and Dexter and coworkers $(1975,1979)$ found a correlation between the wettability of the original solid surface and the rate of bacterial adhesion to a multi-component conditioning film. The latter authors suggested that the adsorbed film itself provides the means of information transferral that could be due to (i) differences in the molecular compositions of the adsorbed protein layers, (ii) differences in the conformation of adsorbed molecules, (iii) differences in the time constants of the adsorption process, or a combination of the above suggestions.

According to the studies of Hlady et al. (1986), Rudee \& Price (1985), Brynda et al. (1984) and Eberhart (1982) on protein adsorption on solid surfaces, the above mentioned differences must be extended to take into account (i) differences in the amount of adsorbed molecules, and (ii) differences in the coverage, i.e. either the presence of a continuous film or a patchwork pattern.

From the studies of Little \& Zsolnay (1985) and Dexter \& Lucas (1985) it is obvious that the transferral is due to more than one difference. In addition, Lundström (1985) observed differences in conformation and amounts of adsorbed protein, even with a single-component protein film.

The aim of this study was twofold: (i) to develop and test a flow cell system for the study of bacterial adhesion under well-defined hydrodynamic conditions; (ii) to establish whether the surface free energy of solid substrata is still of influence on bacterial adhesion after coating with a proteinaceous film.

\section{METHODS}

Flow cell system. The flow cell system developed in our laboratory is based on the systems described by Rutter \& Leech (1980) and Rudee \& Price (1985) and consists of the following parts (shown schematically in Fig. 1): (i) three (or more) flow cells placed in series; (ii) a peristaltic pump (LKB multiperpex 2115); (iii) several flasks containing rinsing solution, fixation solution, bacterial suspension, bovine serum albumin (BSA) solution and waste, respectively. The flask in the centre is used as a damping device and, depending on the stage of the experiment, contained either bacterial suspension, BSA solution or waste.

The flow through the cells is adjusted by hydrostatic pressure in order to get a continuous pulse-free shear rate. The pump transports the different solutions back into the corresponding flasks. By switching the different 


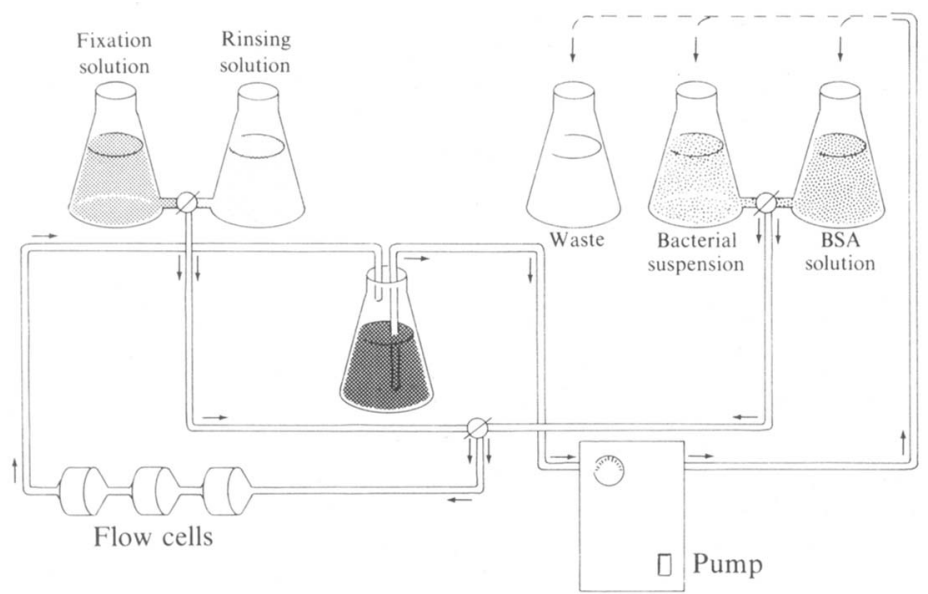

Fig. 1. Schematic representation of the continuous flow system with three flow cells placed in series. The shear rate on the test substrata can be varied by changing the hydrostatic pressure, while liquids are recirculated by a pump.

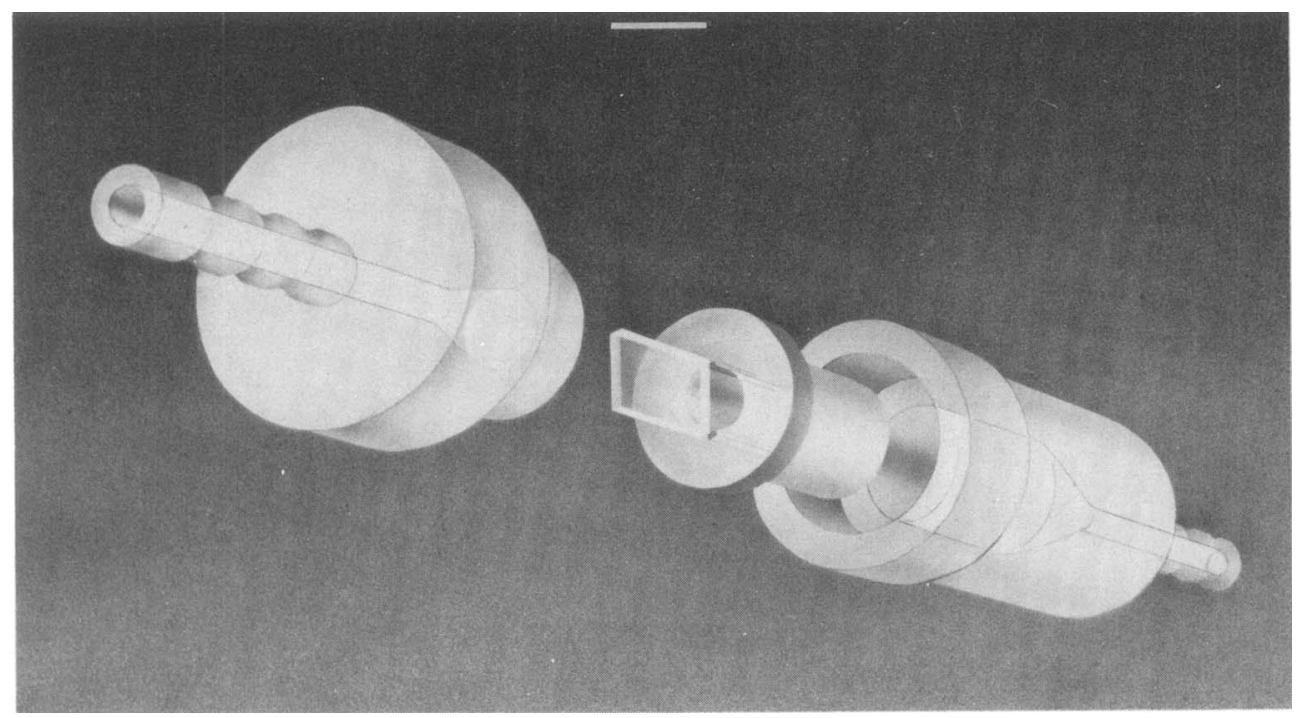

Fig. 2. Expanded view of the flow cell design showing the vertically positioned substratum in the flow chamber with a diameter of $1 \mathrm{~cm}$. The flow cell is made of polymethylmethacrylate. The direction of the flow is from the left. Bar, $1.5 \mathrm{~cm}$.

reservoirs on and off bacterial adhesion, protein coating of the substrata, rinsing and fixation can all be done at the same continuous shear rate and without removing the substratum from the liquid phase.

The flow cell itself (Fig. 2) is constructed of polymethylmethacrylate and holds samples with a thickness varying from $0.1-1.0 \mathrm{~mm}$ and approximately $1 \times 1.5 \mathrm{~cm}$ in size. In the present study, samples were positioned vertically in the flow cell at a hydrostatic height difference of $50 \mathrm{~cm}$, yielding a continuous laminar flow of $60 \mathrm{ml} \mathrm{min}^{-1}$, equivalent to a shear rate of $21 \mathrm{~s}^{-1}$ in the central part of the test substratum. The distribution of the attached bacteria was homogeneous up to $2 \mathrm{~mm}$ from the edges of the sample.

Bacterial strains, solid substrata and BSA coating. Three strains of oral streptococci were selected on the basis of their known, widely different surface free energy, $\gamma_{\mathrm{b}}$. They were Streptococcus mitis BMS $\left(\gamma_{\mathrm{b}}=38 \mathrm{~mJ} \mathrm{~m}^{-2}\right)$, Streptococcus sanguis $12\left(\gamma_{\mathrm{b}}=107 \mathrm{~mJ} \mathrm{~m}^{-2}\right)$ and Streptococcus mutans $\mathrm{NS}\left(\gamma_{\mathrm{b}}=117 \mathrm{~mJ} \mathrm{~m}^{-2}\right)$. Determination of the surface free energy of the bacterial cell surface was described by Busscher et al. (1984). All strains were originally 
isolated from the human oral cavity and were stored at $-20{ }^{\circ} \mathrm{C}$ in Todd Hewitt Broth (Oxoid) containing $7 \%(\mathrm{v} / \mathrm{v})$ dimethylsulphoxide. The bacteria were grown from the frozen state in Todd Hewitt Broth containing $0.5 \%$ glucose overnight at $37^{\circ} \mathrm{C}$. This culture was used to inoculate a second culture which was grown for $16 \mathrm{~h}$ and then harvested by centrifugation. For the adhesion experiments the cells were washed three times with adhesion buffer ( 2 mM-potassium phosphate, $50 \mathrm{~mm}$-potassium chloride, $1 \mathrm{~mm}$-calcium chloride, $\mathrm{pH} 6.8$ ), and suspended in the same buffer.

Three solid substrata were also selected on the basis of their known widely different surface free energy, $\gamma_{\mathrm{s}}$. They were fluorethylenepropylene copolymer (FEP) (Fluorplast, Raamsdonkveer, The Netherlands $\left(\gamma_{\mathrm{s}}=20 \mathrm{~mJ} \mathrm{~m}^{-2}\right)$, cellulose acetate (Hawe Neos Dental, Gentilino, Switzerland) $\left(\gamma_{\mathrm{s}}=58 \mathrm{~mJ} \mathrm{~m}^{-2}\right)$ and glass (microscope slides, Menzel, FRG) $\left(\gamma_{\mathrm{s}}=109 \mathrm{~mJ} \mathrm{~m}^{-2}\right)$. For details of the determination of surface free energy of solid surfaces see Busscher et al. (1983).

The solid substrata were extensively cleaned before the adhesion experiments by successive rinses of $1 \%(w / v)$ sodium dodecylsulphate (SDS), $3 \%(\mathrm{v} / \mathrm{v}) \mathrm{HCl}$ and distilled water. In order to apply a BSA coating the substrata were exposed for $5 \mathrm{~min}$ in the flow cell to $1 \%(\mathrm{w} / \mathrm{v})$ BSA (Cohn fraction V, Sigma) in adhesion buffer at a shear rate of $21 \mathrm{~s}^{-1}$. Thereafter, the substrata were rinsed in the cell for $1 \mathrm{~min}$ with adhesion buffer at the same shear rate.

Adhesion experiments. The substrata with and without a BSA coating were exposed at room temperature to a flowing bacterial suspension containing $10^{9}$ cells $\mathrm{ml}^{-1}$ for various time intervals up to $75 \mathrm{~min}$. For each run three flow cells, each containing a different substratum, were placed in series (Fig. 1).

The entire procedure was done in the flow cell and included coating with BSA (depending on the type of experiment), bacterial adhesion, rinsing for $1 \mathrm{~min}$ with adhesion buffer, fixation for 2 min with $2 \%$ ( $/ \mathrm{v}$ ) glutaraldehyde in adhesion buffer and rinsing with buffer for a further $1 \mathrm{~min}$, respectively. Subsequently, the substrata were removed from the cell, air-dried and stained with $0.5 \%$ crystal violet. The number of attached bacteria was determined in a light microscope by counting ten squares of $2500 \mu \mathrm{m}^{2}$ each in the centre part of the substratum. The number of bacteria $\left(n_{\mathrm{b}}\right)$ adhering at each time, $t$, presented in this study represents the mean from at least four different runs and at least two separate bacterial cultures. Using the approach of Dabros \& van de Ven (1982) the curves representing the number of adhering bacteria versus the flow time were fitted with an iterative least square method, yielding $j_{0}$ and $\tau$, according to

$$
n_{\mathrm{b}}=j_{0} \tau\left(1-\mathrm{e}^{-t / \tau}\right)
$$

where

$n_{\mathrm{b}}$ denotes the no. of bacteria $\mathrm{cm}^{-2}$ adhering at time $t$

$j_{0}$ denotes the initial deposition rate $\left(\mathrm{min}^{-1} \mathrm{~cm}^{-2}\right)$

$\tau$ denotes the relaxation time $(\mathrm{min})$, describing the approach towards equilibrium, due to blocking of adhesion sites by adhering bacteria or desorption

$t$ denotes the flow time (min)

According to equation (4) the number of bacteria adhering at saturation, $n_{\mathrm{b}, \mathrm{s}}$, can be expressed as

$$
n_{\mathrm{b}, \mathrm{s}}=j_{0} \tau
$$

Determination of the surface free energy of uncoated and BSA-coated solid substrata. Surface free energies of uncoated and BSA-coated solid substrata $\left(\gamma_{\mathrm{s}}\right.$ and $\gamma_{\mathrm{s}}^{+}$respectively) were determined from measurements of the advancing contact angle, $\theta$, with sessile droplets of water, water/propan-1-ol mixtures and $\alpha$-bromonaphthalene using the concept of polar and dispersion components with spreading pressures taken into account (Busscher et al., 1983). Before contact angle measurement the BSA-coated substrata were air-dried for $3 \mathrm{~h}$. The interfacial free energies between bacteria, solids and liquid were subsequently computed according to the geometric mean equation (Busscher et al., 1984) from which the interfacial free energies of adhesion to uncoated substrata $\left(\Delta F_{\text {adh }}\right)$ and BSA-coated substrata $\left(\Delta F_{\text {adh }}^{+}\right)$were calculated according to equation (1).

Determination of bound BSA. Substratum-bound BSA was quantified directly on the substrata by using the Lowry method. The BSA-coated substratum was placed in the light path of a $1 \mathrm{~cm}$ cuvette and the reagents were added to the cuvette. After incubation the absorbance was measured at $750 \mathrm{~nm}$ against a similarly treated uncoated substratum.

\section{RESULTS}

Table 1 summarizes the estimated surface free energies and the interfacial free energies of adhesion for uncoated and BSA-coated substrata together with a selection of measured contact angles. From this Table it is evident that a BSA coating strongly reduced the surface free energy of glass whereas it strongly increased the surface free energy of cellulose acetate, yielding similar values. Although the surface free energy of FEP was also markedly increased by coating with 
Table 1. Surface free energies, interfacial free energies of adhesion and measured contact angles

$\gamma_{s}$, Surface free energy $\left(\mathrm{mJ} \mathrm{m}^{-2}\right) ; \Delta F_{\text {adh }}, \Delta F_{\mathrm{adh}}^{+}$, interfacial free energy of adhesion $\left(\mathrm{mJ} \mathrm{m}^{-2}\right)$ of oral streptococci to uncoated substrata and BSA-coated substrata, respectively. $\theta_{\mathrm{H}_{2} \mathrm{O}}, \theta_{\alpha-\mathrm{Br}}$, advancing contact angle measurements (degrees) made with sessile droplets of water and $\alpha$-bromonaphthalene, respectively.

\begin{tabular}{|c|c|c|c|c|c|c|}
\hline \multicolumn{2}{|c|}{ Substratum } & $\begin{array}{l}\text { Without BSA } \\
\text { coating }\end{array}$ & $\begin{array}{l}\text { With BSA } \\
\text { coating }\end{array}$ & Strain & $\Delta F_{\text {adh }}$ & $\Delta F_{\mathrm{adh}}^{+}$ \\
\hline Glass & $\begin{array}{l}\gamma_{\mathrm{s}} \\
\theta_{\mathrm{H}_{2} \mathrm{O}} \\
\theta_{\alpha-\mathrm{Br}}\end{array}$ & $\begin{array}{r}109 \\
26 \\
31\end{array}$ & $\begin{array}{l}82 \\
59 \\
13\end{array}$ & $\begin{array}{l}\text { S. mitis BMS } \\
\text { S. sanguis } 12 \\
\text { S. mutans NS }\end{array}$ & $\begin{array}{r}+13 \\
-7 \\
-13\end{array}$ & $\begin{array}{r}+12 \\
-2 \\
-1\end{array}$ \\
\hline $\begin{array}{l}\text { Cellulose } \\
\text { acetate }\end{array}$ & $\begin{array}{l}\gamma_{\mathrm{s}} \\
\theta_{\mathrm{H}_{2} \mathrm{O}} \\
\theta_{\alpha-\mathrm{Br}}\end{array}$ & $\begin{array}{r}58 \\
78 \\
5\end{array}$ & $\begin{array}{l}80 \\
58 \\
11\end{array}$ & $\begin{array}{l}\text { S. mitis BMS } \\
\text { S. sanguis } 12 \\
S . \text { mutans NS }\end{array}$ & $\begin{array}{r}-49 \\
+6 \\
+9\end{array}$ & $\begin{array}{l}+12 \\
-1 \\
+0.4\end{array}$ \\
\hline FEP & $\begin{array}{l}\gamma_{\mathrm{s}} \\
\theta_{\mathrm{H}_{2} \mathrm{O}} \\
\theta_{\alpha-\mathrm{Br}}\end{array}$ & $\begin{array}{r}20 \\
107 \\
72\end{array}$ & $\begin{array}{l}40 \\
97 \\
29\end{array}$ & $\begin{array}{l}S . \text { mitis BMS } \\
\text { S. sanguis } 12 \\
S . \text { mutans NS }\end{array}$ & $\begin{array}{l}-79 \\
+18 \\
+24\end{array}$ & $\begin{array}{r}-1 \\
+14 \\
+20\end{array}$ \\
\hline
\end{tabular}

BSA, the value remained below those of coated glass and cellulose acetate. Accordingly, the values of $\Delta F_{\text {adh }}$ for the uncoated substrata covered a much broader range than those obtained for the BSA-coated substrata, which had all effectively bound BSA in the following amounts $(\mu \mathrm{g}$ $\mathrm{cm}^{-2} \pm \mathrm{SD}$ ): FEP, $0 \cdot 5 \pm 0 \cdot 1$; glass, $0 \cdot 4 \pm 0 \cdot 1$; cellulose acetate, $0 \cdot 7 \pm 0 \cdot 1$.

Figs 3 and 4 show the numbers of bacteria adhering to the various uncoated $\left(n_{\mathrm{b}}\right)$ and BSAcoated $\left(n_{\mathrm{b}}^{+}\right)$substrata, respectively, as a function of time. In all cases similar kinetics were observed which could be well described by equation (4). The initial deposition rates, $j_{0}$, varied for uncoated substrata from $0.4-3.8 \times 10^{5}$ cells $\mathrm{min}^{-1}$, but decreased for BSA-coated substrata to $0 \cdot 3-2.5 \times 10^{5}$ cells $\mathrm{min}^{-1}$. Also the relaxation times, $\tau$, decreased for all combinations after coating with BSA and varied from 6.3-19.6 min, whereas the values for uncoated substrata varied from 9.3-44.9 min.

The highest numbers of each bacterial strain adhering at saturation to uncoated $\left(n_{\mathrm{b}, \mathrm{s}}\right)$ and BSA-coated $\left(n_{b, s}^{+}\right)$substrata, respectively, were found in systems for which the interfacial free energy of adhesion is most negative (Fig. 5). A strong decrease in adhesion to BSA-coated substrata of each bacterial strain was observed. For each bacterial strain a linear relation existed between the number of adhering bacteria, both in the absence and presence of a BSA coating, and the interfacial free energy of adhesion, $\Delta F_{\text {adh }}$, calculated on the basis of the surface free energy of the bare underlying substratum. The coefficients of correlation for the relation between $n_{\mathrm{b}, \mathrm{s}}$ and $\Delta F_{\mathrm{adh}}$ for each strain were greater than $0 \cdot 95$, while for the relations between $n_{\mathrm{b}, \mathrm{s}}^{+}$ and $\Delta F_{\text {adh }}$ they were greater than 0.88 . This is in contrast to the coefficients of correlation observed between $n_{\mathrm{b}, \mathrm{s}}^{+}$and $\Delta F_{\mathrm{adh}}^{+}$, calculated on the basis of the surface free energy of the BSAcoated substrata, which were $0.45,0.47$ and 0.93 for $S$. mutans NS, $S$. sanguis 12 and $S$. mitis BMS, respectively.

\section{DISCUSSION}

The continuous flow cell system described enabled the study of bacterial adhesion at welldefined shear rates. In addition, it was possible to coat the test substrata with a proteinaceous layer, to rinse the substrata and to fix the attached bacteria under exactly the same shear conditions and without the occurrence of air-solid interfaces. This yielded highly reproducible experimental results, showing interassay coefficients of variation $(n=4-8)$ which for the uncoated substrata varied from $10 \%$ to $15 \%$, whereas for the BSA-coated substrata they varied from $20 \%$ in the high region of $n_{\mathrm{b}, \mathrm{s}}^{+}$to $50 \%$ in the low region of $n_{\mathrm{b}, \mathrm{s}}^{+}$.

The high surface free energy strain $S$. mutans NS showed a clear preference for high surface free energy substrata, whereas the low surface free energy strain $S$. mitis BMS preferred the low 


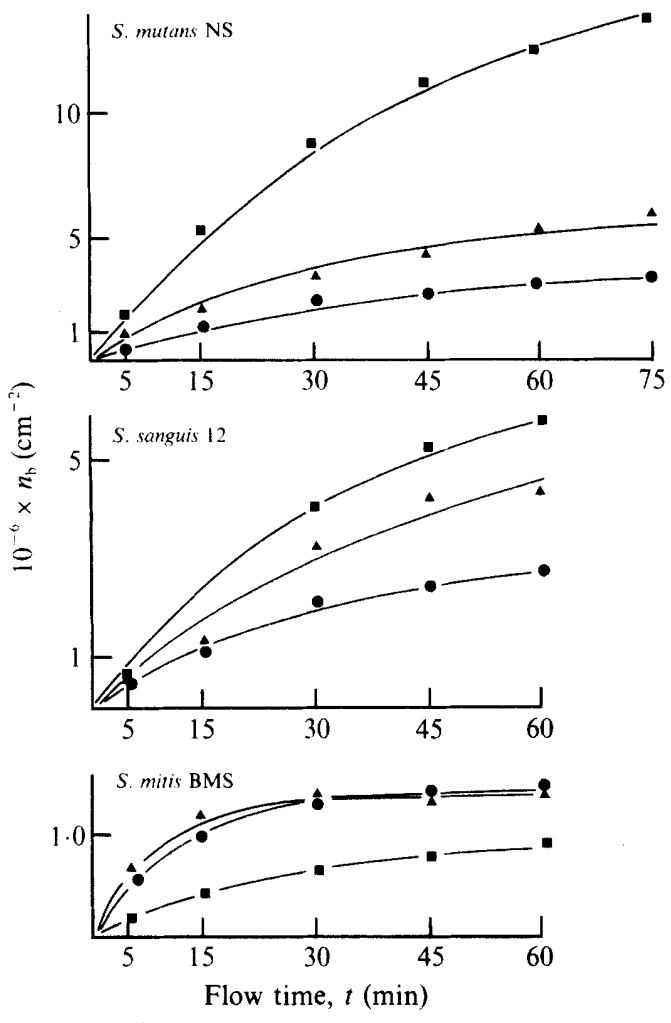

Fig. 3

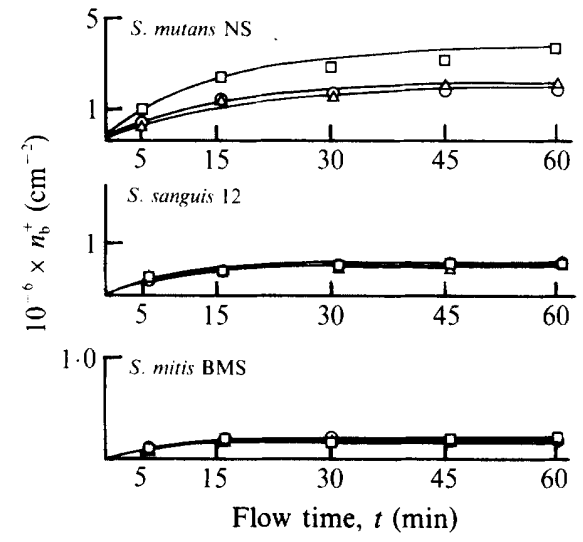

Fig. 4

Fig. 3. Number of bacteria adhering to various uncoated substrata as a function of the flow time. Values are the means of at least four different runs using at least two separate cultures. $\boldsymbol{\square}$, Glass; $\boldsymbol{A}$ cellulose acetate; $\mathbf{O}$, FEP.

Fig. 4. Number of bacteria adhering to various BSA-coated substrata as a function of the flow time. Values are the means of four different runs using two separate bacterial cultures. $\square$, Glass; $\triangle$, cellulose acetate; O, FEP.

surface free energy substrata. This is completely in accordance with expectations based on interfacial free energies of adhesion and corresponds with the findings of Uyen et al. (1985) obtained with a static system. However, these authors were not able to demonstrate a preference of $S$. sanguis $\mathrm{CH} 3$ for any substratum, although based on thermodynamics a slight preference for high surface free energy substrata was expected. In the present study, however, the expected behaviour of $S$. sanguis 12 was observed, which reflects the advantage of a more accurate flow cell system for bacterial adhesion studies.

Like all physico-chemical processes, bacterial adhesion results from a decrease in free energy of the complete system. Such a decrease can be due to changes in interfacial free energy, but also to electrical charge interactions, hydrogen bonds and other specific molecular interactions. If all other contributions could be neglected, no adhesion would be expected if $\Delta F_{\text {adh }}$ is $\geq 0$. All strains however, showed considerable numbers of adhering bacteria at $\Delta F_{\text {adh }} \geq 0$. We suggest that the ability to adhere despite unfavourable interfacial free energy conditions reflects the contribution of other interactions, quantified by the number of bacteria adhering at $\Delta F_{\text {adh }}=0$.

The amounts of BSA adsorbed to the different substrata were similar and in the range $0 \cdot 1-1 \cdot 0$ $\mu \mathrm{g} \mathrm{cm}^{-2}$ as reported by Hlady et al. (1986), Brynda et al. (1984), Horbett (1982) and Brash \& Samak (1978). The BSA coating resulted in smaller differences of $\gamma_{\mathrm{s}}$ between the substrata, although in the case of FEP an influence of the low substratum free energy was still evident. 


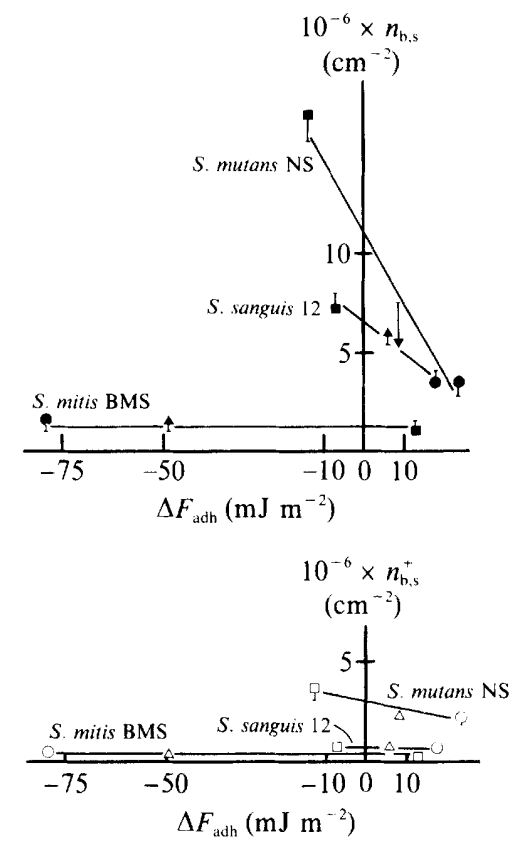

Fig. 5. Number of bacteria adhering at saturation as a function of the interfacial free energy of adhesion. $\square, \mathbf{a}$, Glass; $\triangle, \boldsymbol{\Delta}$, cellulose acetate; $\bigcirc, \boldsymbol{O}$, FEP. Filled symbols denote clean solid substrata; open symbols represent BSA-coated solid substrata. Error bars denote the SD for four different runs using at least two separate bacterial cultures.

Accordingly, smaller differences were observed between the number of bacteria adhering at saturation to BSA-coated substrata but most remarkable was the significant decrease in adhesion for each bacterial strain and on all substrata. A similar effect has been reported for a wide range of different bacteria and substrata (Fletcher, 1976; Gibbons \& Etherden, 1985; Reynolds \& Wong, 1985; Abbott et al., 1983). Analysis of our data showed that $\Delta F_{\text {adh }}$ remained influential on bacterial adhesion to BSA-coated substrata, suggesting that the solid substrata still affect bacterial adhesion despite a protein coating. This phenomenon was noticed previously by Schakenraad et al. (1986) for the adhesion of human fibroblasts to serum-coated substrata and by Fletcher \& Loeb $(1976,1979)$ and Dexter and co-workers $(1975,1979,1985)$ for bacterial adhesion to an adsorbed multi-component organic layer. In this study, where a singlecomponent protein solution was used to coat the solid substrata, preferential adsorption of a specific component, as possible in the above mentioned studies, must be excluded. This indicates that an adsorbed single-component protein layer is capable of transferring the properties of the bare underlying substratum to the interfacial protein layer by adjusting its conformation, the amount adsorbed or the surface area covered by protein. In summary we can draw the following conclusions. (i) The flow cell system developed is suitable for accurate and reproducible studies of bacterial adhesion to solid substrata and in addition for the coating of solid substrata with proteinaceous layers under exactly the same well-defined shear rates as used for bacterial adhesion. (ii) The adhesion of the bacterial strains tested correlates linearly with the interfacial free energy of adhesion, such that the highest numbers adhering for a given strain are found when $\Delta F_{\text {adh }}$ is most negative. (iii) The influence of an adsorbed BSA coating onto the solid substrata is such that: (a) the adhesion of oral streptococci to coated substrata decreases markedly compared with adhesion to uncoated substrata; $(b)$ there remains a distinct influence of the surface free energy of the underlying substratum on adhesion of oral streptococci.

The authors are greatly indebted to Marjon Schakenraad-Dolfing for the preparation of this manuscript. 


\section{REFERENCES}

Abbott, A., Rutter, P. R. \& Berkeley, R. C. W. (1983). The influence of ionic strength, $\mathrm{pH}$ and a protein layer on the interaction between Streptococcus mutans and glass surfaces. Journal of General Microbiology 129, 439-445.

Absolom, D. R., Lamberti, F. V., Policova, Z., ZINGG, W., vaN OsS, C. J. \& NeumanN, A. W. (1983). Surface thermodynamics of bacterial adhesion. Applied and Environmental Microbiology 46, 90-97.

BRash, J. L. \& SAmak, Q. M. (1978). Dynamics of interactions between human albumin and polyethylene surface. Journal of Colloid and Interface Science 65, 495-504.

Brynda, E., Cepalova, N. A. \& Stol, M. (1984). Equilibrium adsorption of human serum albumin and human fibrinogen on hydrophobic and hydrophilic surfaces. Journal of Biomedical Materials Research 18, 685-693.

Busscher, J. J., van Pelt, A. W. J., DE Jong, H. P. \& ARENDS, J. (1983). Effect of spreading pressure on surface free energy determinations by means of contact angle measurements. Journal of Colloid and Interface Science 95, 23-27.

BusSCHER, H. J. WEERKAMP, A. H., VAN DER MEI, H. C., van Pelt, A. W. J., De Jong, H. P. \& ARENDS, J. (1984). Mesurement of the surface free energy of bacterial cell surfaces and its relevance for adhesion. Applied and Environmental Microbiology 48, 980-983.

BussCHer, H. J., Uyen, H. M. W. J. C., WeERKAMP, A. H., Postma, W. J. \& ARends, J. (1986). Reversibility of adhesion of oral streptococci to solids. FEMS Microbiology Letters 35, 303-306.

DABROS, T.\& VAN DE VEN, T. G. M. (1982). Kinetics of coating by colloid particles. Journal of Colloid and Interface Science 89, 232-244.

DEXTER, S. C. (1979). Influence of substratum critical surface tension on bacterial adhesion - in situ studies. Journal of Colloid and Interface Science 70, 346-354.

DeXTER, S. C. \& LuCAS, K. E. (1985). The study of biofilm formation under water by photoacoustic spectroscopy. Journal of Colloid and Interface Science 104, 15-27.

Dexter, S. C., Sullivan, J. D., Williams, S. J. \& WATSON, S. W. (1975). Influence of substratum wettability on the attachment of marine bacteria to various substrata. Applied Microbiology 30, 298-308.

Doyle, R. J., Nesbitt, W. E. \& TAyloR, K. G. (1982). On the mechanisms of adherence of Streptococcus sanguis to hydroxyapatite. FEMS Microbiology Letters 15, 1-5.

Eberhart, R. C., LyNCh, M. E., Bilge, F. H., Wissinger, J. F., Munro, M. S., Ellsworth, S. R. \& QuatTrone, A. J. (1982). Protein adsorption on polymers. Advances in Chemistry Series 199, 293315.

FLETCHER, M. (1976). The effects of proteins on bacterial attachment to polystyrene. Journal of General Microbiology 94, 400-404.

Fletcher, M. \& LOEB, G. I. (1976). The influence of substratum surface properties on the attachment of a marine bacterium. In Colloid and Interface Sciences, vol. III, pp. 459-469. Edited by M. Kerker. New York: Academic Press.

Fletcher, M. \& LOEB, G. I. (1979). Influence of substratum characteristics on the attachment of a marine pseudomonad to solid surfaces. Applied and Environmental Microbiology 37, 67-72.

Fletcher, M. \& Pringle, J. H. (1985). The effect of surface free energy and medium surface tension on bacterial attachment to solid surfaces. Journal of Colloid and Interface Science 104, 5-14.

GibBons, R. J. (1980). Adhesion of bacteria to the surfaces of the mouth. In Microbial Adhesion to Surfaces, pp. 351-378. Edited by R. C. W. Berkeley, J. M. Lynch, J. Melling, P. R. Rutter \& B. Vincent. Chichester: Ellis Horwood.

GibBons, R. J. \& ETHERdEN, J. (1985). Albumin as a blocking agent in studies of streptococcal adsorption to experimental salivary pellicles. Infection and Immunity 50, 592-594.

Hlady, V., Reinecke, D. R. \& AndRade, J. D. (1986). Fluorescence of adsorbed protein layers. Journal of Colloid and Interface Science 111, 555-569.

HorbetT, T. A. (1982). Protein adsorption on biomaterials. Advances in Chemistry Series 199, 233-244.

LitTle, B. J. \& Zsolnay, A. (1985). Chemical fingerprinting of adsorbed organic materials on metal surfaces. Journal of Colloid and Interface Science 104, 79-86.

LUNDSTRÖM, I. (1985). Protein conformation at surfaces. In Oral Interfacial Reactions of Bone, Soft Tissue and Saliva, pp. 9-23. Edited by P.-O. Glantz, S. A. Leach \& T. Ericson. Oxford: IRL Press.

van OSs, C. J., Good, R. J. \& Chaudhury, M. K. (1987). Determination of the hydrophobic interaction energy - application to separation processes. Separation Science Technology 22, 1-12.

REYNoldS, E. C. \& Wong, A. (1983). Effect of adsorbed protein on hydroxyapatite zeta potential and Streptococcus mutans adherence. Infection and Immunity 39, 1285-1290.

Rosenberg, M., Gutnick, D. \& Rosenberg, E. (1980). Adherence of bacteria to hydrocarbons: a simple method for measuring cell surface hydrophobicity. FEMS Microbiology Letters 9, 29-33.

RudeE, M. L. \& PrICE, T. M. (1985). The initial stages of adsorption of plasma derived proteins on artificial surfaces in a controlled flow environment. Journal of Biomedical Materials Research 19, 57-66.

RUTTER, P. \& LEECH, R. (1980). The deposition of Streptococcus sanguis NCTC 7868 from a flowing suspension. Journal of General Microbiology 120, 301-307.

SCHAKENRAad, J. M., Busscher, H. J., WildevuUR, C. R. H. \& ARENDS, J. (1986). The influence of substratum free energy on growth and spreading of human fibroblasts in the presence and absence of serum proteins. Journal of Biomaterials Research $\mathbf{2 0}$, 773-784.

UYEN, M. H. W. J. C., BussCheR, H. J., WeERKAMP, A. H. \& ARENDS, J. (1985). Surface free energies of oral streptococci and their adhesion to solids. FEMS Microbiology Letters 30, 303-306.

WeERKamp, A. H., van der Mei, H. C., Engelen, D. P. E. \& DE WINDT, C. E. A. (1984). Adhesion receptors (adhesins) of oral streptococci. In Bacterial Adhesion and Preventive Dentistry, pp. 85-97. Edited by J. M. TEN CATE, S. A. Leach \& J. Arends. Oxford: IRL Press. 